\title{
Tension-Free Mini-Invasive Anti-Incontinence Procedures: Comparison Among Three Main Pathways
}

\author{
Vito Leanza*
}

Surgery Department, Catania University Urogynecology Unit, Catania University

\begin{abstract}
Objective. To evaluate both results and complications of Retro-pubic, Pre-pubic and Trans-obturator miniinvasive anti-incontinence surgical procedures.

Material and methods. Search of PubMed, Cochrane library and relevant articles from 1996 to 2012.

Results. Seventy-four works were found. Literature showed similar cure rates among retro-pubic (71,4-91\%), transobturator (77,3-95\%) and pre-pubic (81-87,2\%) anti-incontinence procedures. Cystoscopy is considered as necessary in the retro-pubic, optional in the trans-obturator, unnecessary in the pre-pubic procedure. Intra-operative cough stress test is believed to be useful only when using the retro-pubic and the pre-pubic path. Obstruction symptoms prevail in the retropubic, are rare in the trans-obturator and not recorded in the pre-pubic procedure. The erosion rate is similar for the all the three techniques. Permanent catheterization is found in 3\% of the retro-pubic technique group. The retro-pubic path may be mainly performed for the cure of recurrent stress incontinence (RSI) and intrinsic sphincter deficiency (ISD) in absence of obstructive symptoms. Due to the danger involved in the retro-pubic space, intra-operative vascular and perforating risks prevail in the retro-pubic procedure, whereas the onset of late infective complications in the trans-obturator technique is due to the site of the mesh tip that may interfere with the movements of the thigh. No severe complications were reported in the pre-pubic procedure.
\end{abstract}

Conclusion. In the severe cases of SUI, RSI and in ISD the retro-pubic tension-free route remains the favourite; when obstructive symptoms prevail, the prepubic technique is the most appropriate; whereas for all other cases, the trans-obturator procedure is the most suitable.

Keywords: Urinary incontinence, Pre-pubic TVT, Retro-pubic TVT, TOT, mid-urethral sling.

\section{INTRODUCTION}

Urinary incontinence affects physical, emotional, psychological, social and sexual wellbeing, so resulting into a major impact on women's quality of life [1]. Stress Urinary Incontinence (SUI) is the most common cause of urine leakage, accounting for approximately $50 \%$ of incontinence in women [2]. It is characterized by the patient's complaint of involuntary leakage either under effort or physical exertion, or when sneezing or coughing [3].

According to the late ( $>5$-year) follow-up, approximately $85 \%$ of cases are cured. Advantages include fewer incisions, less anaesthesia, shorter hospitalization and faster patient's recovery, up to the point that they can go back to their daily activities [4].

A number of synthetic materials have been developed and impressive reductions in surgical morbidity have been achieved. The use of synthetic meshes has reduced operating time and eliminated the morbidity at the autologous graft harvest site [5]. The characteristics of different meshes differ

*Address correspondence to this author at the Surgery Department, Catania University Urogynecology Unit Catania University; Tel: 003934622 77116; E-mail: vito.leanza@gmail.com in terms of their fibres, weave, porosity and flexibility. These properties affect the response of tissues and the capacity for incorporation into the host's tissues or for fighting infection. The synthetic material that results in the best tissue incorporation is monofilament macroporous polypropylene mesh. Although many different studies reported high cure rates using the retro-pubic approach, peri-operative complications have been described that include intestinal, vascular and bladder injuries [6-8].

In an attempt to reduce these complications, Delorme et al. [9] developed a procedure by which the sling is introduced via the obturator foramen. The retro-pubic area is conserved and cystoscopy is unnecessary, reducing the duration and cost of surgery.

The pre-pubic route was introduced, once more, to make the anti-incontinence procedure easier.

Aim of this study is to compare the three main antiincontinence routes: retro-pubic, trans-obturator and prepubic (Fig. 1).

\section{MATERIAL AND METHODS}

A Medline bibliographical research of the most relevant reviews regarding retro-pubic, trans-obturator and pre-pubic 


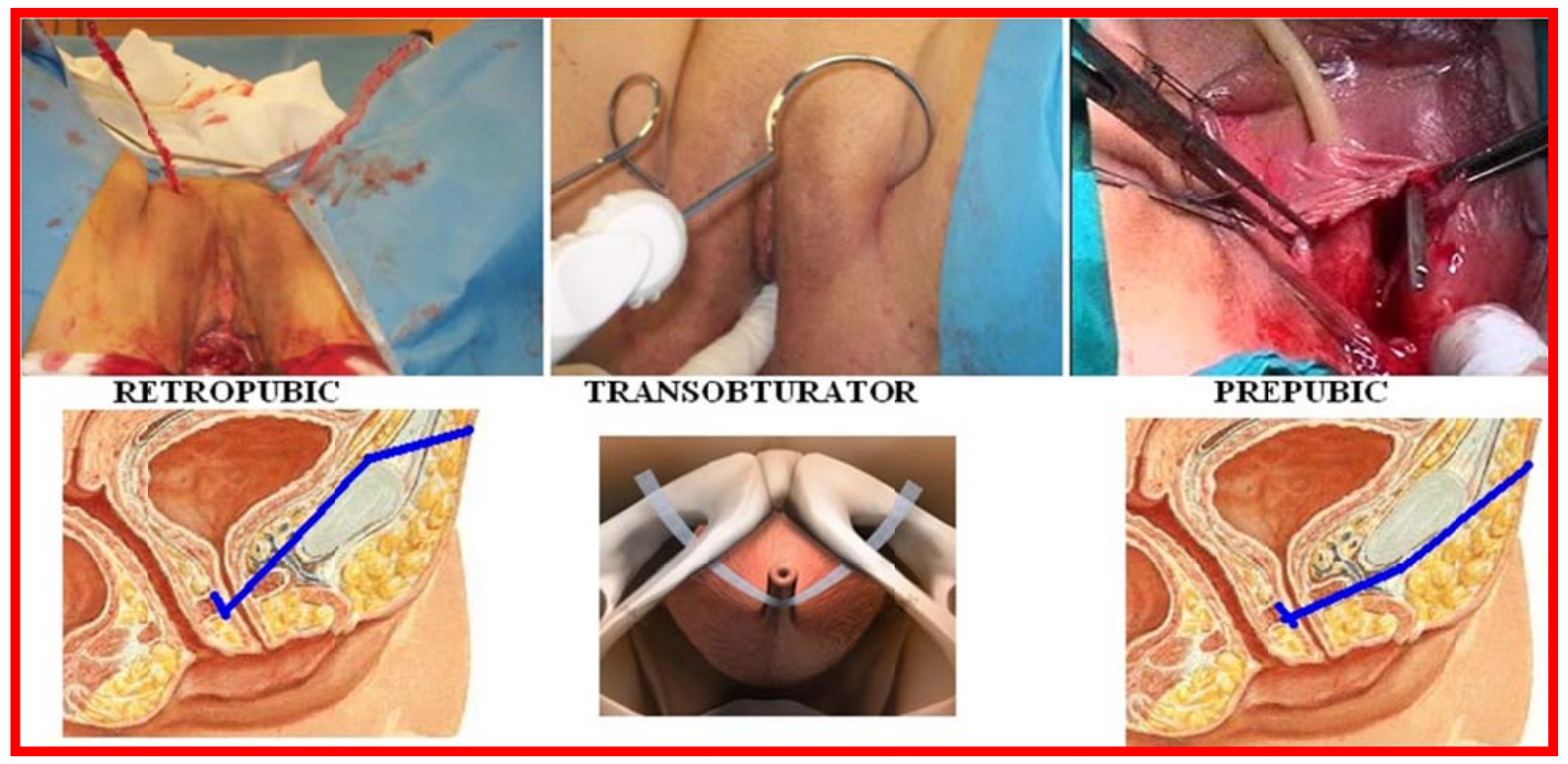

Fig. (1). Retro-pubic, trans-obturator and pre-pubic tension-free procedures.

mini-invasive anti-incontinence procedures between 1996 and 2012 was done.

\section{Retro-Pubic Mini-Invasive Procedures}

The retro-pubic tension-free vaginal tape (TVT) was introduced by Ulmsten in 1996 as a mini-invasive surgery for the treatment of urinary stress incontinence. Several other mini-invasive retro-pubic procedures followed the TVT. Retro-pubic TVT is a minimally invasive mid-urethral sling that is passed through the retro-pubic space: it was designed to replace functionally deficient pubo-urethral ligaments. With the patient in lithotomic position, 3 small incisions are made: 2 supra-pubic and one on the anterior vaginal wall at the mid-urethral level. The excess sling is trimmed. Cystoscopy is then performed to make sure no bladder perforations occurred. In this case the direction of the wings is vertical and the intra operative stress test is performed.

\section{Trans-Obturator Procedure}

The pioneer of the trans-obturator sub-urethral procedure (TOT) was Delorme in 2001. The aim of TOT was to reduce the range of the retro-pubic complications. Three incisions are made: two small incisions in the groin lateral to the lower pubic ramus, and one vaginal incision in the mid-urethral area. The needles are inserted in the groin incision and passed into the mid-urethral incision (out-in) or vice versa (in-out). The direction of the wings is horizontal and intraoperative stress test is not necessary. Once the tape is well placed, it is adjusted to the appropriate tension. The sheath is then removed, the excess mesh trimmed from the surgical site, and the incisions are sutured. Cystoscopy is optional [9].

\section{Pre-Pubic Tvt Procedure}

The pre-pubic mini-invasive procedure implies the use of a mid-urethral sling in which the tape crosses the space placed in front of the pubic bone. It was introduced to facilitate the anti-incontinence techniques through a less risky pathway.
With the woman in the lithotomy position, three small incisions are made: two pre-pubic and one on the anterior vaginal wall crosswise the midurethra. The eye needles are then passed from the vagina to the supra-pubic area. The tape is adjusted following the stress test. Excess sling is then trimmed. Cystoscopic check-up is not necessary.

In Holly's series [10], the rates of objectively assessed treatment success were $80.8 \%$ in the retro-pubic-sling group and $77.7 \%$ in the trans-obturator-sling group. The rates of subjectively assessed success were $62.2 \%$ and $55.8 \%$, respectively. The rates of voiding dysfunction requiring surgery were $2.7 \%$ in those who received retro-pubic slings and $0 \%$ in those who received trans-obturator slings. There were no significant differences between groups as far as postoperative urge incontinence, satisfaction with the results of the procedure, or quality of life are concerned.

Liapis et al [11] carried out a comparative study and concluded that the two routes are equally effective for surgical treatment of SUI, with cure rates of $90 \%$ and $89 \%$, respectively.

Mellier et al [12] conducted a similar study and observed cure rates of $90 \%$ for the retro-pubic approach and $95 \%$ for the trans-obturator approach. Similarly, Lee et al [13] reported a cure rate of $86.9 \%$ in both groups.

A randomized controlled trial of TOT versus TVT with a 12-month follow-up showed that TOT is as safe and effective as TVT in treating women with stress urinary incontinence [14]. Objective cure rates were $71.4 \%$ for TVT and $77.3 \%$ for TOT $[15,16]$.

Palma et al. [17] compared the efficacy of different surgical techniques, and did not detect any difference in terms of the cure rates, which were $92.1 \%$ using the supra-pubic vaginal approach and $94 \%$ using the trans-obturator approach. However, the trans-obturator technique was less time-consuming and the rate of complications such as bladder perforation (2.3\% and 0\%, respectively) and postoperative urgency (20.6\% and $10 \%$, respectively) was much 
lower. The sling became infected in $4.7 \%$ of the retro-pubic group and $1 \%$ of the trans-obturator group. None of the trans-obturator patients suffered from urine retention, which affected $3.1 \%$ of the retro-pubic patients. The sling was adjusted in $4.7 \%$ of the retro-pubic patients, (with a cure rate of $66.6 \%$ ), and in $6 \%$ of trans-obturator patients (cure rate of $83.3 \%$ ). There were no complications such as bleeding or vaginal or urethral perforation.

The incidence rates of bladder perforation range from $0.8 \%$ to $21 \%$ among patients treated using the retro-pubic technique $[11,13,18-21)$. On the other hand, few cases of bladder or urethra perforation are reported during transobturator surgery [11,13,21].

Rechberger et al. concluded that both approaches are effective for the treatment of stress urinary incontinence. Nevertheless, the retro-pubic technique was found to be more effective for sphincter deficiency [ISD] [22]. Kuuva et al. [23] observed $0.8 \%$ of infection of the surgical wound. Rarer infectious complications that have also been observed include infected hematoma and necrotizing fasciitis [24]. Complications observed after trans-obturator surgery include inguinal and obturator abscesses, as well as perineal cellulites $[25,26]$.

Tanuri [27] compared TVT and TOT techniques; they found out that the rate of bladder perforation was of 3.3\% in the retro-pubic group without any other complications. Improvement in the quality of life was similar for both groups. $90 \%$.

In both groups, subjective and objective cure rates were

They observed a $25 \%$ failure rate among the eight patients with pressure at leakage below $60 \mathrm{~cm} \mathrm{H2O}$ after TOT procedure.

No significant differences were detected between the groups in terms of postoperative complications. All urinary tract infections were solved by antibiotic therapy. There was one case of urine retention in the retro-pubic group, that we settled using a catheter.

One patient in the TOT group reported a mild sporadic pain in the medial surface of the left thigh which improved with analgesics, but continued to be present at all follow-up.

6 months after surgery both subjective and objective cure rates were $90 \%$ in both groups. After 12 months, the subjective cure rate was $90 \%$ in the TOT group and $88.8 \%$ in the retro-pubic group.

Regarding the IDS, a $25 \%$ failure rate using the transobturator approach and $0 \%$ of failures in the retro-pubic group were observed. Although the sample is small, these data are similar to those reported from recent clinical trials. There was one retro-pubic case with urinary urgency and one case in each group of urge incontinence symptoms. There were no cases of post-operative infection and no cases of vaginal erosion of the sling.

Hammad et al. [28] reported a 1.2\% rate of vaginal erosion after retro-pubic TVT.

There is a higher risk of vaginal erosion with the TOT rather then with the TVT approach. Groin abscesses have been reported using TOT [29] and are more common with certain types of sling material [30,31].

Juma and Brito [29] found lower rates of persistent urge incontinence (21/130 [16\%]) and de novo urge incontinence $(1 / 130$ [2\%]).

In a study published in 2007 Meschia et al. found no significant differences [32] after comparing the classic retropubic TVT with the trans-obturator TVT (TVT-O), .

Silvia (2007) reported no difference in cure rates or complications among the in-out and out-in TOT. The short-term efficacy of TOT mid-urethral slings was comparable with the retro-pubic slings; however, preliminary evidence suggested that TOT slings may have a lower success rate compared with retro-pubic slings for the treatment of intrinsic sphincter deficiency [33].

There is now a significant body of Literature showing the success of TVT for the treatment of stress urinary incontinence. A number of prospective observational trials have been conducted to evaluate the effectiveness of the TVT procedure [34-39].

Trans-obturator tape and retro-pubic tension-free vaginal tapes are comparable in terms of efficacy [40]. For patients with recurrent incontinence, the results are similar to those achieved with a primary procedure; for those with a fixed urethrovesical junction, the outcome is poor, as it is with any other surgical procedures [41-43]. Holmgren conducted a long-term study, published in 2005, concluding that initial cure rates of TVT were good for mixed incontinence but did not persist after four years [44].

Concerns about the safety of retro-pubic mid-urethral slings have been prompted by a growing number of case reports of complications, including injury to the bowel, major vessels, and bladder, and urethral perforation. Complications with retro-pubic slings also include bleeding, hematoma, erosion of the mesh into the urethra or vagina, bladder perforation, de novo urge symptoms, voiding dysfunction, and infection [45-48]. Rarer case reports include delayed bowel erosion, bowel injury, bowel obstruction, urethral diverticulum, vesical calculi, paraurethral abscess, necrotizing fasciitis, fistulas, urethral erosions, and nerve damage [4954]. However, Ammendrup et al. note that TVT procedure complication rates are low, with very few serious complications [55].

Giberti et al. carried out a two-year follow-up study on women with stress urinary incontinence treated with TOT and found an objective cure rate of $80 \%$ [56], whereas Cindolo et al. observed a cure rate of $92 \%$ [57].

De Leval et al. [58] found neither vesical nor urethral injuries and stated that the trans-obturator approach is a safe procedure not requiring intra-operative cystoscopy.

Postoperative groin pains were reported and they decreased in two months follow-up [59]. Although transobturator approaches avoid the retro-pubic area, a higher risk of damage to the obturator vessels is to be considered $[60,61]$.

Arrabal-Polo MA et al. [62] reported more complications with patients treated by retro-pubic procedures (26\%) when 
compared with patients using the trans-obturator surgical procedure(12\%).

There are few Literature works showing the outcomes of pre-pubic route for the treatment of stress urinary incontinence. Some trials have been conducted to evaluate the effectiveness of this procedure [63-71]. Daher et al. [63] reported a $87,2 \%$ subjective cure, $4.3-7 \%$ improvement and 6$13,4 \%$ failures.

No significant intra- and post-operative complications occurred. In a Multicenter Randomized Trial, Leanza et al. compared the pre-pubic with the retro-pubic procedure. [64] In the pre-pubic, subjectively, incontinence was cured in $177(87.2 \%)$. Objectively, S.U.I. was cured in 175 cases (86.2\%). The cystocele was cured 173 (85.2\%) patients. Postoperative complications included neither cases of "de novo" instability nor obstruction, whereas 13 (6.4\%) patients suffered from urge-incontinence, 14 (6.9\%) patients from urgency and 9 (4.4\%) patients from pollakiuria. 5 cases (2.5\%) of erosion were observed: they had been treated by the excision of protruding mesh without suturing the vaginal skin and the pelvic floor was not compromised. During follow-up, two other pelvic procedures were requested. Postoperative Q tip test average was 27 degrees (range 12-51). A significant difference in VAS scores and in the majority of the main domains was found in King's Health Questionnaire regarding preoperative and postoperative data $(\mathrm{p}<0.001)$, whereas the results of the pre-pubic procedure were comparable to the retro-pubic one. Besides, subject satisfaction was not significantly different between retro and pre-pubic TICT: 88 versus $89 \%$.

In another study [65] both procedures (pre-pubic and retro-pubic) for the treatment of Recurrent Stress Incontinence (RSI) were compared. The retro-pubic was found to be more effective to solve RSI ( $83.3 \%$ versus $76.7 \%$ ); yet, the retro-pubic procedure had a higher rate of complications (7.4\% of voiding difficulties). Trans-obturator technique late complications such as severe troubles when walking have never been reported with the retro-pubic and pre-pubic procedures [66-74] (Table 1).

\section{CONCLUSION}

The retro-pubic, the trans-obturator and the pre-pubic approaches are minimally invasive and are effective for the treatment of stress urinary incontinence. They minimize morbidity, improve the quality of life with low complications, reduce costs and recovery time. There was no statistical difference between the 3 approaches in terms of clinical or urodynamic results, quality of life assessment, pad test or number of complications.

Intra-operative vascular and perforating risks prevail in the retro-pubic due to the anatomic danger of the retro-pubic space; whereas late infective complications are higher in the trans-obturator procedure owing to the site of the mesh tip that may interfere with thigh movements. Severe complications in the pre-pubic were not reported, but this kind of surgery is rarely performed.

Pre-pubic mini-invasive procedure is a simple technique with very low risks and the preliminary results are consistent with those of other published techniques.

When compared with the retro-pubic, the pre-pubic one is simpler, non-obstructive but less stable.

The complications (bladder perforation, vascular or nervous damages) found in the tension-free retro-pubic procedures are less in the trans-obturator and disappear in the prepubic route. Finally, in the severe cases of SUI, RSI and in ISD the retro-pubic tension-free route remains the favourite; when obstructive symptoms prevail, the prepubic technique is the most appropriate; whereas for all other cases, the transobturator procedure is the most suitable.

\section{CONFLICT OF INTEREST}

The authors confirm that this article content has no conflicts of interest.

\section{ACKNOWLEDGEMENTS}

None Declared.

Table 1. Complication of Retro-Pubic, TOT and Pre-Pubic Techniques (\%)

\begin{tabular}{|c|c|c|c|c|c|c|}
\hline & CURE RATE & FAILURE RATE & $\begin{array}{l}\text { URINARY UR- } \\
\text { GENCY }\end{array}$ & INFECTIONS & $\begin{array}{l}\text { BLADDER OR } \\
\text { URETRAL PER- } \\
\text { FORATION }\end{array}$ & $\begin{array}{l}\text { URINE RETEN- } \\
\text { TION }\end{array}$ \\
\hline Trans-obturatory & $77,3-95 \%$ & $2,2-25 \%$ & $4,44-10 \%$ & $1-4,4 \%$ & $0.5 \%$ & $0-55,8 \%$ \\
\hline $\begin{array}{l}\text { Retro-pubic versus } \\
\text { pre-pubic }\end{array}$ & $\begin{array}{l}X^{2}=0,46 \\
p>0,05 \text { (NS) }\end{array}$ & $\mathrm{p}>0,05$ (NS) & $\begin{array}{l}X^{2}=7,47 \\
p>0,05 \text { (NS) }\end{array}$ & $\begin{array}{l}X^{2}=0,82 \\
p>0,05 \text { (NS) }\end{array}$ & & \\
\hline $\begin{array}{l}\text { T.O.T. versus } \\
\text { pre-pubic }\end{array}$ & $\begin{array}{l}X^{2}=0,13 \\
p>0,05 \text { (NS) }\end{array}$ & $p>0,05$ (NS) & $\begin{array}{l}X^{2}=0,68 \\
p>0,05 \text { (NS) }\end{array}$ & $\begin{array}{l}X^{2}=0,82 \\
p>0,05 \text { (NS) }\end{array}$ & & \\
\hline
\end{tabular}




\section{REFERENCES}

[1] Samuelsson E, Victor A, Svardsudd K. Determinants of urinary incontinence in a population of young and middle-aged women. Acta Obstet Gynecol Scand 2000; 79: 208-15.

[2] Hannestad YS, Rortveit G, Sandvik H, Hunskaar S. A communitybased epidemiological survey of female urinary incontinence: the Norwegian EPINCONT study. Epidemiology of Incontinence in the county of nord-trondelag. J Clin Epidemiol 2000; 53: 1150-7.

[3] Abrams P, Cardozo L, Fall M, et al. The standardisation of terminology of lower urinary tract function: report from the Standardisation Sub-committee of the International Continence Society. Neurourol Urodyn 2002; 21: 167-78.

[4] Novara G, Ficarra V, Boscolo-Berto R, Secco S, Cavalleri S, Artibani W. Tension-free mid-urethral slings in the treatment of female stress urinary incontinence: a systematic review and meta-analysis of randomized controlled trials of effectiveness. Eur Urol 2007; 52: 663-78.

[5] Norris JP, Breslin DS, Staskin DR. Use of synthetic material in sling surgery: a minimally invasive approach. J Endourol 1996; 10: 227-30.

[6] Meschia M, Pifarotti P, Bernasconi F, et al. Tension-Free vaginal tape: analysis of outcomes and complications in 404 stress incontinent women. Int Urogynecol J Pelvic Floor Dysfunct 2001; 12(Suppl 2): S24-S7.

[7] Nilsson CG. Latest advances in TVT tension-free support for urinary incontinence. Surg Technol Int 2004; 12: 171-6.

[8] Holmgren C, Nilsson S, Lanner L, Hellberg D. Long-term results with tension-free vaginal tape on mixed and stress urinary incontinence. Obstet Gynecol 2005; 106: 38-43.

[9] Delorme E. Trans-obturator urethral suspension: mini-invasive procedure in the treatment of stress urinary incontinence in women. Prog Urol 2001; 11: 1306-13.

[10] Richter HE, Michael E, Halina M, et al. Retro-pubic versus transobturator mid-urethral slings for stress incontinence. N Engl J Med 2010; 362(22): 2066-76.

[11] Liapis A, Bakas P, Giner M, Creatsas G. Tension-free vaginal tape versus tension-free vaginal tape obturator in women with stress urinary incontinence. Gynecol Obstet Invest 2006; 62: 160-4.

[12] Mellier G, Benayed B, Bretones S, Pasquier JC. Sub-urethral tape via the obturator route: is the TOT a simplification of the TVT? Int Urogynecol J Pelvic Floor Dysfunct 2004; 15: 227-32.

[13] Lee KS, Han DH, Choi YS, et al. A prospective trial comparing tension-free vaginal tape and trans-obturator vaginal tape inside-out for the surgical treatment of female stress urinary incontinence: 1year followup. J Urol 2007; 177: 214-8.

[14] Porena M, Costantini E, Frea B, et al. Tension-free vaginal tape versus trans-obturator tape as surgery for stress urinary incontinence: results of a multicentre randomized trial. Eur Urol 2007; 52: 1481-90.

[15] Falkert A, Seelbach-Gobel B. TVT versus TOT for surgical treatment of female stress urinary incontinence. Int J Gynaecol Obstet 2007; 96(1): 40-1.

[16] Schierlitz LHE, Dwyer PL, Roasmilia A, et al. A randomized controlled study to compare tension free vaginal tape (TVT) and MONARC trans-obturator tape in the treatment of women with urodynamic stress incontinence (USI) and intrinsic sphincter deficiency (ISD). Int Urogynecol J 2007; 18(Suppl 1): S19.

[17] Palma P, Riccetto C, Herrmann V, et al. Trans-obturator SAFYRE sling is as effective as the transvaginal procedure. Int Urogynecol $\mathrm{J}$ Pelvic Floor Dysfunct 2005; 16: 487-91.

[18] Meschia M, Pifarotti P, Bernasconi F, et al. Tension-Free vaginal tape: analysis of outcomes and complications in 404 stress incontinent women. Int Urogynecol J Pelvic Floor Dysfunct 2001; 12(Suppl 2): S24-S7.

[19] Debodinance P, Delporte P, Engrand JB, Boulogne M. Tensionfree vaginal tape (TVT) in the treatment of urinary stress incontinence: 3 years experience involving 256 operations. Eur J Obstet Gynecol Reprod Biol 2002; 105: 49-58.

[20] Abouassaly R, Steinberg JR, Lemieux M, et al. Complications of tension-free vaginal tape surgery: a multi-institutional review. BJU Int 2004; 94: 110-3.

[21] Zullo MA, Plotti F, Calcagno M, et al. One-year follow-up of tension-free vaginal tape (TVT) and trans-obturator sub-urethral tape from inside to outside (TVT-O) for surgical treatment of female stress urinary incontinence: a prospective randomised trial. Eur Urol 2007; 51: 1376-82.

[22] Rechberger T, Futyma K, Jankiewicz K, Adamiak A, Skorupski P. The clinical effectiveness of retro-pubic (IVS-02) and transobturator (IVS-04) mid-urethral slings: randomized trial. Eur Urol 2009; 56: 24-30.

[23] Kuuva N, Nilsson CG. A nationwide analysis of complications associated with the tension-free vaginal tape (TVT) procedure. Acta Obstet Gynecol Scand 2002; 81: 72-7.

[24] Johnson DW, ElHajj M, OBrien-Best EL, Miller HJ, Fine PM. Necrotizing fasciitis after tension-free vaginal tape (TVT) placement. Int Urogynecol J Pelvic Floor Dysfunct 2003; 14: 291-3.

[25] Domingo S, Alama P, Ruiz N, Perales A, Pellicer A. Diagnosis, management and prognosis of vaginal erosion after trans-obturator sub-urethral tape procedure using a nonwoven thermally bonded polypropylene mesh. J Urol 2005; 173: 627-30.

[26] Cindolo L, Salzano L, Rota G, Bellini S, DAfiero A. Tension-free trans-obturator approach for female stress urinary incontinence. Minerva Urol Nefrol 2004; 56: 89-98.

[27] Tanuri AL, Feldner PC Jr, Bella ZI, et al. Retro-pubic or transobturator slings for treatment of stress urinary incontinence. Rev Assoc Med Bras 2010; 56(3). 348-54.

[28] Hammad FT, Kennedy-Smith A, Robinson RG. Erosions and urinary retention following polypropylene synthetic sling: Australasian survey. Eur Urol 2005; 47: 641-6.

[29] Juma S, Brito C. Trans-obturator tape (TOT): two years follow-up. Neurourol Urodyn 2007; 26: 37-41.

[30] Robert M, Murphy M, Birch C, Swaby C, Ross S. Five cases of tape erosion after trans-obturator surgery for stress incontinence. Obstet Gynecol 2006; 107(2 Pt 2): 472-4.

[31] Dobson A, Robert M, Swaby C, et al. Trans-obturator surgery for stress urinary incontinence: 1 year follow-up of a cohort of 52 women. Int Urogynecol J Pelvic Floor Dysfunct 2007; 18(1): $27-$ 32.

[32] Meschia M, Bertozzi R, Pifarotti P, et al. Peri-operative morbidity and early results of a randomised trial comparing TVT and TVT-O. Int Urogynecol J Pelvic Floor Dysfunct 2007; 18: 1257-61.

[33] Silva WA. Treatment of stress urinary incontinence-mid-urethral slings: top-down, bottom-up, “outside-in,” or "inside-out.” Clin Obstet Gynecol 2007; 50(2): 362-75.

[34] Nilsson CG, Falconer C, Rezapour M. Seven-year follow-up of the tension-free vaginal tape procedure for treatment of urinary incontinence. Obstet Gynecol 2004; 104: 1259-62.

[35] Rezapour M, Ulmsten U. Tension-free vaginal tape (TVT) in women with recurrent stress urinary incontinence-a long-term follow-up. Int Urogynecol J Pelvic Floor Dysfunct 2001; 12 (Suppl 2): S9-S11.

[36] Rezapour M, Ulmsten U. Tension free vaginal tape (TVT) in women with mixed urinary incontinence-a long-term follow-up. Int Urogynecol J Pelvic Floor Dysfunct 2001; 12(Suppl 2): S15-8.

[37] Rezapour M, Falconer C, Ulmsten U. Tension-free vaginal tape (TVT) in stress incontinent women with intrinsic sphincter deficiency (ISD)-a long-term follow-up. Int Urogynecol J Pelvic Floor Dysfunct 2001; 12(Suppl 2): S12-14.

[38] Deffieux X, Donnadieu AC, Porcher R, Gervaise A, Frydman R, Fernandez $\mathrm{H}$. Long-term results of tension-free vaginal tape for female urinary incontinence: follow-up over 6 years. Int $\mathrm{J}$ Urol 2007; 14: 521-6.

[39] Moran PA, Ward KL, Johnson D, Simirni WE, Hilton P, Bibby J. Tension-free vaginal tape for primary genuine stress incontinence: a two-centre follow-up study. BJU Int 2000; 86: 39-42.

[40] Chêne G, Amblard J, Tardieu AS, et al. Long-term results of tension-free vaginal tape (TVT) for the treatment of female stress urinary incontinence. Eur J Obstet Gynecol Reprod Biol 2007; 134: 87-94.

[41] Rezapour M, Ulmsten U. Tension-free vaginal tape (TVT) in women with recurrent stress urinary incontinence-a long-term follow-up. Int Urogynecol J Pelvic Floor Dysfunct 2001; 12(Suppl 2): S9-S11.

[42] Rezapour M, Falconer C, Ulmsten U. Tension-free vaginal tape (TVT) in stress incontinent women with intrinsic sphincter deficiency (ISD)-a long-term follow-up. Int Urogynecol J Pelvic Floor Dysfunct 2001; 12(Suppl 2): S12-14.

[43] Clemons JL, LaSala CA. The tension-free vaginal tape in women with a non-hypermobile urethra and low maximal urethral closure pressure. Int Urogynecol J Pelvic Floor Dysfunct 2007; 18: 727-32. 
[44] Holmgren C, Nilsson S, Lanner L, Hellberg D. Long-term results with tension-free vaginal tape on mixed and stress urinary incontinence Obstet Gynecol 2005; 106: 38-43.

[45] Huang KH, Kung FT, Liang HM, Huang LY, Chang SY. Concomitant surgery with tension-free vaginal tape. Acta Obstet Gynecol Scand 2003; 81: 948-53.

[46] Azam U, Frazer M, Kozman E, Ward K, Hilton P, Rane A. The tension-free vaginal tape procedure in women with previous failed stress incontinence surgery. Urology 2001; 166: 554-6.

[47] Neuman M. Transvaginal suture placement for bleeding control with the tension-free vaginal tape procedure. Int Urogynecol J Pelvic Floor Dysfunct 2006; 17(2): 176-7.

[48] Karram MM, Segal JL, Vassallo BJ, Kleeman SD. Complications and untoward effects of the tension-free vaginal tape procedure. Obstet Gynecol 2003; 101(5 Pt 1): 929-32.

[49] Fourie T, Cohen P. Delayed bowel erosion by tension-free vaginal tape (TVT). Int Urogynecol J Pelvic Floor Dysfunct 2003; 14: 3624.

[50] Leboeuf L, Mendez LE, Gousse AE. Small bowel obstruction associated with tension-free vaginal tape. Urology 2004; 63(6): 1182-4.

[51] Hammad FT. TVT can also cause urethral diverticulum. Int Urogynecol J Pelvic Floor Dysfunct 2007; 18(4): 467-9.

[52] Tate SB, Franco AV, Fynes MM. Tension-free vaginal tape exposure presenting as a recurrent sterile paraurethral abscess. Int Urogynecol J Pelvic Floor Dynfunct 2005; 16(5): 420-3.

[53] Johnson DW, ElHajj M, Obrien-Bewt EL, Miller JH, Fine PM. Necrotizing faciitis after tension-free vaginal tape (TVT) placement. Int Urogynecol J Pelvic Floor Dysfunct 2003; 14(4): 291-3.

[54] Siegel Al. Urethral necrosis and proximal urethra-vaginal fistula resulting from tension-free vaginal tape. Int Urogynecol J Pelvic Floor Dysfunct 2006; 17(6): 661-4.

[55] Ammendrup A, Bendixen A, Sander P, Lose G. Short-term complications after urinary incontinence surgery in Denmark from 2001 to 2003. Int Urogynecol J 2007; 18 (Suppl 1): S18.

[56] Giberti C, Gallo F, Cortese P, Schenone M. Trans-obturator tape for treatment of female stress urinary incontinence: objective and subjective results after a mean follow-up of two years. Urology 2007; 69(4): 703-7.

[57] Cindolo L, Salzano L, Rota G, Bellini S, D’Afiero A. Tension-free trans-obturator approach for female stress urinary incontinence. Minerva Urol Nefrol 2004; 56(1): 89-98.

[58] De Leval J. Novel surgical technique for the treatment of female stress urinary incontinence: trans-obturator vaginal tape inside-out. Eur Urol 2003; 44: 724-30.

[59] Laurikainen E, Valpas A, Kivela A, et al. Retro-pubic compared with trans-obturator tape placement in treatment of urinary incontinence: a randomized controlled trial. Obstet Gynecol 2007; 109(1): 4-11.
[60] Bonnet P, Waltregny D, Reul O, deLeval J. Trans-obturator vaginal tape inside out for the surgical treatment of female stress urinary incontinence: anatomical considerations. J Urol 2005; 173: 1223-8.

[61] Darai E, Frobert J, Grisard-Anaf M, et al. Functional results after the sub-urethral sling procedure for urinary stress incontinence: a prospective randomized multicentre study comparing the retropubic and trans-obturator routes. Eur Urol 2007; 51: 795-802.

[62] Arrabal-Polo MA, Palao-Yago F, Zuluaga-Gómez A, et al. Complications from the placement of a tension-free sub-urethral sling using the trans-obturator and retro-pubic methods for treatment of female urinary incontinence. Urol Int 2012; 89: 97-102.

[63] Daher N, Gagneur O, Gondry J, Mention JE, Merviel P, Boulanger JC. Gynecol. Pre-pubic TVT: a prospective study of 164 female patients treated for stress urinary incontinence. Obstet Fertil 2005; 33(9): 570-6.

[64] Leanza V, Dati S, Gasbarro N. A multicenter randomized trial of pre-pubic and retro-pubic leanza-gasbarro-caschetto tension-free procedures. Int Urogynecol J 2009; 20(supp2): 73-39,001.

[65] Leanza V, Dati S, Gasbarro N. Retro-pubic and pre-pubic polypropylene mid-urethral procedures: techniques and outcomes. Urogynaecol Int J 2009; 23 (2): 75-8.

[66] Daher N, Boulanger JC, Ulmsten U. Pre-pubic TVT: an alternative to classic TVT in selected patients with urinary stress incontinence. Eur J Obstet Gynecol Reprod Biol 2003; 107(2): 205-7.

[67] Lukacz ES, Luber KM, Nager CW. The effects of the tension-free vaginal tape on voiding function: a prospective evaluation. Int Urogynecol J Pelvic Floor Dysfunct 2004; 15: 32-8.

[68] Leanza V, Dati S, Gasbarro N. Pre-pubic pathway in the treatment of stress urinary incontinence (SUI) and cystocele. Int Urogynecol J 2007; 18(Suppl 1); S107-S 244,165.

[69] Leanza V, Dati S, Leanza G, Gasbarro N, Sciorio C. Pre-pubic tension-free urethral suspension (p-tus) in the treatment of recurrent stress urinary incontinence. Urogynaecol Int J 2010; 24 (1): 60-8.

[70] Leanza V, Dati S, Gasbarro N, Leanza G. Retro-pubic versus transobturator tension free procedures: a comparative study. Neurourol Urodyn 2011; 30: S1 1-54.

[71] Leanza V, Accardi M. Late mesh erosion in a patient with previous trans-obturator tape procedure associated with severe claudicatio: case report. Urogynaecol Int J 2007; 21 (2): 96-99.

[72] Leanza V, Passanisi A, Leanza G. A specific application of two psychological measures on female urinary incontinence: perceived negative affective self-efficacy scale and stress psychological measure. Urogynaecol Int J 2011; 25 (2): 41-8.

[73] Leanza V, Intagliata E, Vecchio R, Leanza G, Cannizzaro MA. Retropubic, transobturator and prepubic mininvasive antincontinence procedures: state of art. Urogynaecol Int J 2011; 25 (2): 191205.

[74] Dati S, Leanza V, Leanza GP. Rombolà, TVT-Abbrevo continence procedure. Urogynaecol Int J 2011; 25 j(2): 131-3.

Received: July 07, 2012

Revised: August 28, 2012

Accepted: August 28, 2012

(C) Vito Leanza; Licensee Bentham Open.

This is an open access article licensed under the terms of the Creative Commons Attribution Non-Commercial License (http://creativecommons.org/licenses/by-nc/3.0/) which permits unrestricted, non-commercial use, distribution and reproduction in any medium, provided the work is properly cited. 